\title{
In vitro bactericidal activity of equine platelet concentrates, platelet poor plasma, and plasma against methicillin-resistant Staphylococcus aureus
}

\author{
Actividad bactericida in vitro de concentrados de plaquetas, plasma pobre en plaquetas \\ y plasma de equinos contra Staphylococcus aureus resistente a la meticilina
}

\author{
ME Álvarez ${ }^{\mathrm{a}}, \mathrm{C}$ López $^{\mathrm{a}, \mathrm{b}}, \mathrm{CE}$ Giraldo $^{\mathrm{a}}$, I Samudio ${ }^{\mathrm{c}}$, JU Carmona $^{\mathrm{a}}$ \\ ${ }^{a}$ Grupo de Investigación Terapia Regenerativa, Departamento de Salud Animal, Universidad de Caldas, Manizales, Caldas, \\ Colombia. \\ bBecaria COLCIENCIAS “Generación Bicentenario”, Programa de Doctorado en Ciencias Biomédicas, Universidad de Caldas, \\ Manizales, Caldas, Colombia. \\ Departamento de Nutrición y Bioquímica, Pontificia Universidad Javeriana, Bogotá, Colombia.
}

\begin{abstract}
RESUMEN
Los objetivos del estudio fueron: 1) evaluar el efecto antibacteriano de concentrados de plaquetas equinas (ePC) (activados o no con gluconato de calcio (CG)) frente a Staphylococcus aureus meticilino-resistente (MRSA) y 2) comparar su efecto antibacteriano contra plasma pobre en plaquetas (PPP) (activado con CG -PPP/GC-) y plasma (P). Los productos sanguíneos fueron divididos en 4 grupos (ePC, ePC/CG, PPP/CG y P), más un grupo control positivo (PCG) y otro control negativo. Los grupos se mezclaron con caldo Mueller-Hinton y MRSA. Las muestras fueron incubadas durante 1, $4,8,12$ y 24 horas y se contaron las unidades formadoras de colonias. El crecimiento de las bacterias fue significativamente $(\mathrm{P}=0,01)$ inhibido por el ePC, ePC/CG, PPP/CG y P en comparación con el PCG durante las primeras $12 \mathrm{~h}$. Sólo a las 24 horas hubo una diferencia estadísticamente significativa $(\mathrm{P}=0.01)$ y se observó un efecto antibacteriano para el ePC, ePC/CG y PPP/CG en comparación con el PCG y P. Los ePCs y PPP equinos mostraron el mejor efecto antibacteriano in vitro contra el MRSA.
\end{abstract}

Key words: equine platelet rich plasma, antimicrobial effect, infection, Staphylococcus aureus.

Palabras clave: plasma rico en plaquetas de caballo, efecto antimicrobiano, infección, Staphylococcus aureus.

\section{INTRODUCTION}

The use of autologous platelet concentrates (also known as platelet rich plasma -PRP-) as treatment for chronic musculoskeletal diseases, such as osteoarthritis (Carmona et al 2009 ), tendonitis (Carmona et al 2009 ), desmitis of the suspensory ligament (Waselau et al 2008, Carmona et al 2009 ${ }^{\text {b) }}$, skin wounds (Monteiro et al 2009) and as adjuvant in both soft tissue and orthopaedic surgery, has gained great interest in equine practice. The rationale for these clinical purposes stems from the fact that platelets store and release (upon activation) growth factors such as transforming growth factors beta (Argüelles et al 2006, Carmona et al 2008), platelet derived growth factors, fibroblastic derived growth factors, epidermal growth factor, and hepatocyte derived growth factor and other molecules that increase the wound healing process (Sutter et al 2004).

In addition to the regenerative and anti-inflammatory properties of the PRP; recently, the clinical (Yuan et al 2008) and in vitro (Bielecki et al 2007, Moojen et al 2008)

Accepted: 12.01 .2011

* Calle $65 \mathrm{~N}^{\circ}$ 26-10, Manizales, Caldas, Colombia; carmona@ucaldas.edu.co antibacterial effect of human platelet concentrates have been reported against bacteria such as Staphylococcus aureus (sensible (Bielecki et al 2007, Moojen et al 2008) and methicillin resistant-MRSA-) and, Escherichia coli (Bielecki et al 2007), amongst others. The mechanism of the antibacterial effect of PRP is not fully understood, although some evidence suggests that platelets could play pivotal role in antimicrobial host defence, since these cell fragments contain molecules with microbicidal effect, mainly, thrombin-induced platelet microbicidal protein-1 (tPMP-1), a protein similar to human platelet factor 4 (PF-4) (Yount et al 2004). tPMP-1 has an important antibacterial effect against Staphylococcus aureus (Mukhopadhyay et al 2007, Trier et al 2008). Platelets release other microbicidal proteins such as thymosin-b4, the derivatives of CXCL7, (PBP, CTAP-III, NAP-2), and CCL5 (RANTES) (Trier et al 2008). Platelet alpha-granules also contain complement and complement binding proteins, such as precursor of the complements $\mathrm{C} 3$ and $\mathrm{C} 4$ that participate in the complement pathway activation (Blair and Flaumenhaft 2009).

Methicillin-resistant Staphylococcus aureus is a very common nosocomial pathogen affecting humans and pets. The biggest problem caused by MRSA colonization and infection is the resistance of this pathogen against all $\beta$-lactam antibiotics and therefore treatment is difficult and often limited (Weese 2004, Weese and Rousseau 2005). 
In the veterinary field, the presence of infections caused by MRSA seems to be an emerging problem in horses, veterinarians, equine hospitals and staff working with these animals (Weese 2004, Weese and Rousseau 2005, Weese and Lefebvre 2007).

Staphylococcus aureus is one of the most common bacteria isolated from normal skin (Alvarez et al 2010), and in surgical infections is related to colic (Ingle-Fehr et al 1997), orthopaedic surgery (Macdonald et al 1994), metritis, pneumonia, catheter site infections (Weese 2004) and septic arthritis or synovitis in horses (Pille et al 2009). Recently, a study conducted in 206 horses with septic synovitis reveled that 23 horses $(34.3 \%)$ were positive for Staphylococcus aureus of which 7 (30.3\%) were subjected to euthanasia by the non-resolution of the infection (Taylor et al 2010). However, these infections could potentially be more grave when produced by MRSA strains, although this situation has not been fully proven in horses (Anderson et al 2009).

Up until now there is no information about the in vitro antibacterial effect of the equine platelet concentrates (ePCs) and other equine blood components against MRSA. The aims of this study were to evaluate the antibacterial effect of ePCs (either activated or not with calcium gluconate (CG)) obtained by the tube method (Argüelles et al 2006) against MRSA, and to compare their antibacterial effect with activated platelet poor plasma (PPP) and plasma (P).

\section{MATERIALS AND METHODS}

The study was approved by a local Ethical Committee.

\section{HORSES}

Seven clinically normal Colombian Creole horses were used in the study: 2 geldings, and 5 mares, age 4-12 years (mean 7.7 years). All animals were stabled at a riding school and were fed and managed under the same conditions.

\section{BLOOD COLLECTION AND PREPARATION OF THE PLATELET} CONCENTRATES AND THE OTHER BLOOD COMPONENTS

Blood samples were processed by the tube method (Argüelles et al 2006) for obtaining ePCs and PPP. After skin disinfection, $40 \mathrm{~mL}$ of whole blood per horse was drawn with a 21 gauge butterfly catheter and collected in tubes with sodium citrate $3.2 \%$ (BD Vacutainer systems, Plymoth, UK). After centrifugation at $120 \mathrm{~g}$ for $5 \mathrm{~min}$, the first supernatant plasma fraction $(50 \%)$, adjacent to the buffy coat (figure 1) was removed under aseptic conditions in a clean laboratory environment (Alvarez et al 2010). This fraction was then centrifuged at $240 \mathrm{~g}$ for $5 \mathrm{~min}$ and $25 \%$ of the first fraction collected (figure 1) was drawn into sterile syringes and considered as ePC (Argüelles et al 2006). Three $\mathrm{mL}$ of $\mathrm{ePC}$ of each horse was used. Additionally, $2 \mathrm{~mL}$ of PPP and $1 \mathrm{~mL}$ of plasma were used in the study (figure 1).
Platelet poor plasma was considered as the first top $\mathrm{mL}$ of the fraction centrifuged at $240 \mathrm{~g}$ for $5 \mathrm{~min}$ (figure 1). Plasma was obtained by centrifugation of citrated blood at $2400 \mathrm{~g}$ for $8 \mathrm{~min}$ (Arguielles et al 2006). The average time between blood extraction and the initiation of sample processing was 30 minutes. Equine PCs, PPPs, and citrated blood (basal count) were analyzed by duplicate for automatized count of platelets (PLT) and white blood cells (WBC).

\section{ANTIBACTERIAL ASSAY}

The cellular blood products (ePCs and PPP) and plasma were analysed to determine their antibacterial effect against a strain of MRSA (ATCC ${ }^{\circledR} 43300$, Oxoid Culti-Loops ${ }^{\circledR}$, C9022L, KS, USA) that was previously incubated during 18-24h. This strain of MRSA has been previously used in several studies (Strukova et al 2009, Karska-Wysocki et al 2010). The groups were allotted as a follow, ePC (1 mL of ePC), ePC/CG (0.9 mL of ePC plus $0.1 \mathrm{~mL}$ of CG), PPP/

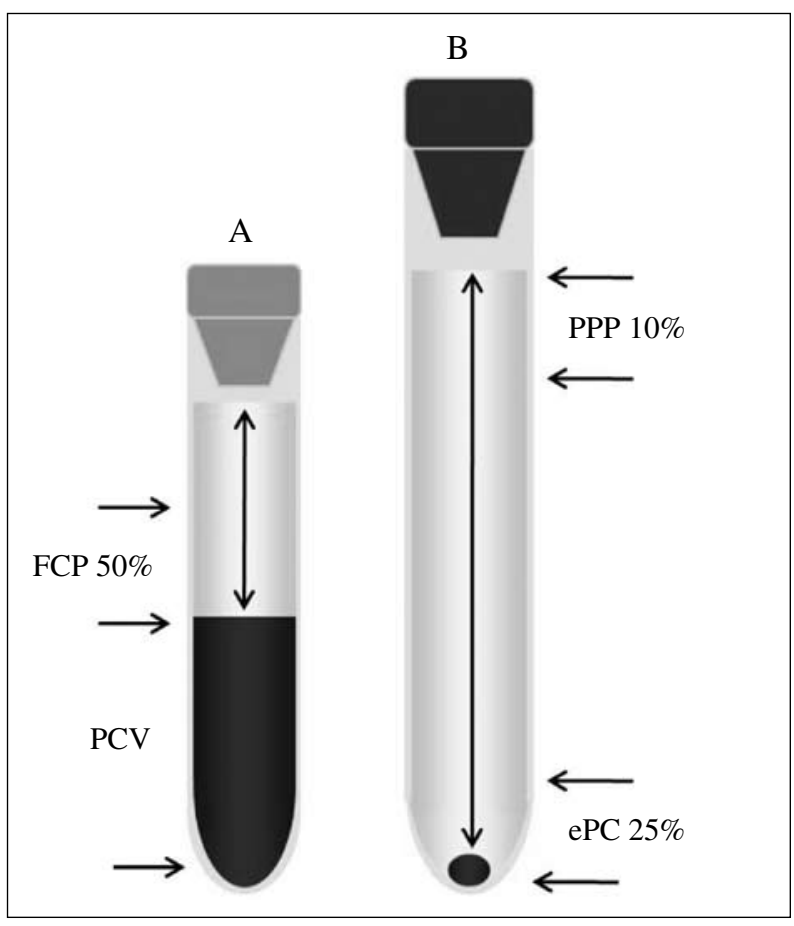

Figure 1. Tube A (with sodium citrate) represents the first $50 \%$ plasma fraction (FCP -first centrifugation plasma-) obtained at $120 \mathrm{~g}$ for $5 \mathrm{~min}$. Tube $\mathrm{B}$ (without additive) represents the plasma obtained after spun FCP at $240 \mathrm{~g}$ for $5 \mathrm{~min}$. ePC $=$ Equine platelet concentrate. $\mathrm{PCV}=$ Packed cellular volume $\mathrm{PPP}=$ Platelet poor plasma.

El tubo A (con citrato de sodio) representa la primera fracción de plasma 50\% (FCP plasma de primer centrifugado) obtenida a $120 \mathrm{~g}$ por $5 \mathrm{~min}$. El tubo B (sin aditivo) representa el plasma obtenido después de centrifugar FCP a $240 \mathrm{~g}$ por $5 \mathrm{~min}$. ePC $=$ Concentrado de plaquetas equinas. $\mathrm{PCV}=$ paquete de volumen celular. $\mathrm{PPP}=$ plasma pobre en plaquetas. 
CG $(0.9 \mathrm{~mL}$ of PPP plus $0.1 \mathrm{~mL}$ of calcium gluconate (-9.3 mg/mL-) (Ropsohn Therapeutics Ltda ${ }^{\circledR}$, Bogotá, Colombia), and $\mathrm{P}$ (1 $\mathrm{mL}$ of plasma). One $\mathrm{mL}$ of each sample was mixed with $33 \mu \mathrm{L}$ of a MRSA suspension and $4 \mathrm{~mL}$ of Mueller-Hinton broth (MHB) (Oxoid Ltd., KS, USA) to obtain a final concentration of $1 \times 10^{6}$ colony-forming units $(\mathrm{CFU}) / \mathrm{mL}$. Furthermore, a positive control group (PCG) $(1 \mathrm{~mL}$ of PBS $+33 \mu \mathrm{L}$ of MRSA suspension $+4 \mathrm{~mL}$ of $\mathrm{MHB}$ ) and a negative control group (NCG) (1mL of PBS $+4 \mathrm{~mL}$ of MHB) were also included.

The samples were incubated by duplicate at $37^{\circ} \mathrm{C}$ during $1,4,8,12$, and $24 \mathrm{~h}$ and plated in serial 10 -fold dilutions $(1: 10,1: 100,1: 1,000,1: 10,000$ and $1: 100,000)$ in plates of sheep blood agar to $5 \%$. The plates were incubated at $37{ }^{\circ} \mathrm{C}$ during $24 \mathrm{~h}$ (Moojen et al 2008), and the number of CFU was determined manually in each plate. The highest growth recorded for any sample was limited to $300 \mathrm{CFU} /$ plate for the all dilutions. The number of $\mathrm{CFU} / \mathrm{mL}$ was determined by the following formula: $\mathrm{CFU} / \mathrm{mL}=\mathrm{CFU} /$ plate $\mathrm{x}(1 / 0.01 \mathrm{~mL}$ aliquot plated $) \mathrm{x}$ dilution factor.

\section{STATISTICAL ANALYSIS}

Data were analyzed using the software SPSS 17.0 (SPSS Inc, Chicago, IL, USA). The hematological (PLT and WBC counts) values were presented as mean ( \pm s.d) and evaluated with a one way ANOVA. A Student-Newman-Keuls was used as post-hoc test. The antibacterial effect of each evaluated group was presented as median (interquartile range) and evaluated with a Friedman's ANOVA. Tests of Wilcoxon and Mann-Whitney U were used as posthoc tests. Data were analyzed with non-parametric tests since they did not present a parametric distribution and it was no possible to obtain a normal distribution of CFU/ $\mathrm{mL}$ counts after several transformations, including ${ }^{10} \mathrm{Log}$ transformation. Counts of CFU/mL from the 1:10.000 dilution were considered for the statistical analysis. A Spearman correlation test $\left(\mathrm{r}_{\mathrm{s}}\right)$ was also performed between haematological values and counts of CFU/mL. A P $<0.05$ value was accepted as statistically significant for the all tests. The results of the NCG were no considered for the statistical analysis since its values always were zero.

The power and the sample size of the study were calculated using online free software ${ }^{1}$. The calculated power for the variables evaluated was performed by determination of the percentage of bacterial growth inhibition among groups. The bacterial growth registered $(\mathrm{CFU} / \mathrm{mL}$ $\mathrm{x} 10^{8}$ ) for the PCG each time $(1,4,8,12$, and $24 \mathrm{~h})$ was considered as $100 \%$ value. The calculated power for this study was $0.8(80 \%)$ using a sample size of 7 horses and an alpha error level of $1 \%$.

www.dssresearch.com/toolkit/spcalc/power_p2.asp) (DDS Research, Fort Worth, TX, USA

\section{RESULTS}

HAEMATOLOGICAL VALUES

The mean counts of PLT and WBC in citrated blood (basal counts) samples were 210,214 $\pm 39,760 / \mu \mathrm{L}$ and $11600 \pm 1400 / \mu \mathrm{L}$, respectively. The mean PLT count for the ePCs was $512,928 / \mu \mathrm{L}$ and $9,560 \pm 4,980 \mathrm{WBC} / \mu \mathrm{L}$. The mean PLT concentration for PPPs was 257,215 \pm 59,511 $\mathrm{PLT} / \mu \mathrm{L}$ and $128 \pm 165 \mathrm{WBC} / \mu \mathrm{L}$. The concentration of PLT/ $\mu \mathrm{L}$ was statistically different $(\mathrm{P}<0.01)$ between the basal count of the whole blood and the ePCs and between the PLT count of the ePCs and PPPs. There were no statistical differences among the PLT counts for whole blood and the PPPs. The WBC concentration in PPPs was statistically lower $(\mathrm{P}<0.01)$ than in whole blood samples and in the ePCs. There were no statistical differences between the WBC count in citrated blood and the ePCs.

\section{COMPARISON OF THE ANTIBACTERIAL EFFECT OF THE EQUINE BLOOD COMPONENTS DURING TIME}

The bacterial growth was significantly $(\mathrm{P}<0.01)$ inhibited in the ePC, ePC/CG, $\mathrm{PPP} / \mathrm{CG}$ and $\mathrm{P}$ groups in comparison with the PCG during the first hour. There were significant differences among $\mathrm{PPP} / \mathrm{CG}$ and $\mathrm{P}$ with a better antibacterial $(\mathrm{P}<0.01)$ effect for PPP/CG (table 1$)$. At $4 \mathrm{~h}$ ePC, ePC/CG, PPP/CG and P groups presented a significant $(\mathrm{P}<0.01)$ antibacterial effect against MRSA in comparison with the PCG, but no statistical differences was noticed for each blood component evaluated (table 1). At $8 \mathrm{~h}$ all the equine blood component groups presented a significant antibacterial effect against MRSA $(\mathrm{P}<0.01)$ in comparison with the PCG (figure 2), although the PPP/ CG presented an statistically $(\mathrm{P}<0.01)$ better antibacterial effect than ePC and $\mathrm{P}$ groups (table 1 ).

The bacterial growth continued to be significantly $(\mathrm{P}<0.01)$ inhibited by the ePC, ePC/CG, PPP/CG and P groups in comparison with the $\mathrm{PCG}$ at $12 \mathrm{~h}$. At that time, PPP/CG followed by ePC/CG presented the best tendency of antibacterial effect in comparison with the other blood components and they (PPP/CG and ePC/CG) were statistically different from plasma group (table 1). At $24 \mathrm{~h}$ only a statistically significant $(\mathrm{P}<0.01)$ antibacterial effect was noticed for the ePC, ePC/CG and PPP/CG groups in comparison with the plasma and PCG, while these last two groups were not statistically different (table 1).

\section{BEHAVIOR OF THE ANTIBACTERIAL EFFECT OF EACH BLOOD COMPONENT DURING TIME}

The positive control group showed an exponential bacterial growth during time. When each time for the PCG was compared, significant $(\mathrm{P}<0.01)$ differences were noticed between the first hour and the other time points $(4,8,12$ and $24 \mathrm{~h})$, between $4 \mathrm{~h}$ and $12 \mathrm{~h}$ and $24 \mathrm{~h}$, 
Table 1. Antibacterial effect of the equine blood components during time (1:10,000 dilution)*

Efecto antibacteriano de los componentes de sangre equina en el tiempo (dilución 1:10.000).

\begin{tabular}{lccccc}
\hline \multirow{2}{*}{ Blood component } & \multicolumn{5}{c}{ CFU/mL x 10 } \\
\cline { 2 - 6 } & $1 \mathrm{~h}$ & $4 \mathrm{~h}$ & $8 \mathrm{~h}$ & $12 \mathrm{~h}$ & $24 \mathrm{~h}$ \\
\hline $\begin{array}{l}\text { Positive control group (PCG) } \\
\text { Equine platelet concentrate (ePC) }\end{array}$ & $30(30)$ & $290(430)$ & $1,290(1150)$ & $1,740(370)$ & $3,000(0)$ \\
$\begin{array}{l}\text { Equine platelet concentrate plus } \\
\text { calcium gluconate (ePC/CG) }\end{array}$ & $0(10)^{\mathrm{a}}$ & $0(10)^{\mathrm{a}}$ & $80(110)^{\mathrm{a}}$ & $310(340)^{\mathrm{a}, \mathrm{e}}$ & $2,050(1360)^{\mathrm{a}, \mathrm{f}}$ \\
$\begin{array}{l}\text { Platelet poor plasma plus calcium } \\
\text { gluconate (PPP/CG) }\end{array}$ & $0(10)^{\mathrm{a}}$ & $50(80)^{\mathrm{a}}$ & $550(510)^{\mathrm{a}}$ & $1,320(1440)^{\mathrm{a}, \mathrm{f}}$ \\
$\begin{array}{l}\text { Plasma (P) } \\
\text { Pla }\end{array}$ & $10(10)^{\mathrm{a}}$ & $0(0)^{\mathrm{a}}$ & $20(60)^{\mathrm{a}, \mathrm{c}, \mathrm{d}}$ & $330(230)^{\mathrm{a}, \mathrm{e}}$ & $1,660(330)^{\mathrm{a}, \mathrm{f}}$ \\
\hline
\end{tabular}

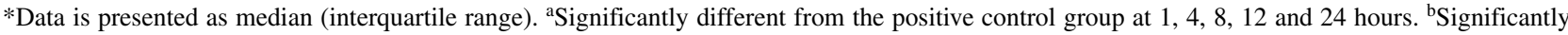
different from the plasma group at $1 \mathrm{~h}$. ${ }^{\mathrm{c}}$ Significantly different from the equine platelet concentrate group at $8 \mathrm{~h}$. ${ }^{\mathrm{d}}$ Significantly different from the plasma

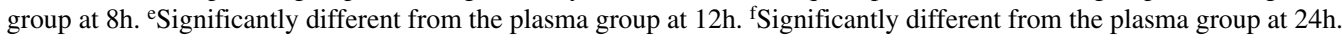

*Los datos se presentan como mediana (rango intercuartílico). a'Significativamente diferente del grupo control positivo en $1,4,8,12$ y 24 horas. ${ }^{b}$ Significativamente diferente del grupo tratado con plasma en $1 \mathrm{~h}$. 'Significativamente diferente del grupo de concentrado de plaquetas equinas a las $8 \mathrm{~h}$. ${ }^{\mathrm{d} S i g n i f i c a t i v a m e n t e ~ d i f e r e n t e ~ d e l ~ g r u p o ~ t r a t a d o ~ c o n ~ p l a s m a ~ a ~ l a s ~} 8 \mathrm{~h}$. ${ }^{\mathrm{e}}$ Significativamente diferente del grupo tratado con plasma a las $12 \mathrm{~h}$. ${ }^{\mathrm{f}}$ Significativamente diferente del grupo tratado con plasma a las $24 \mathrm{~h}$.
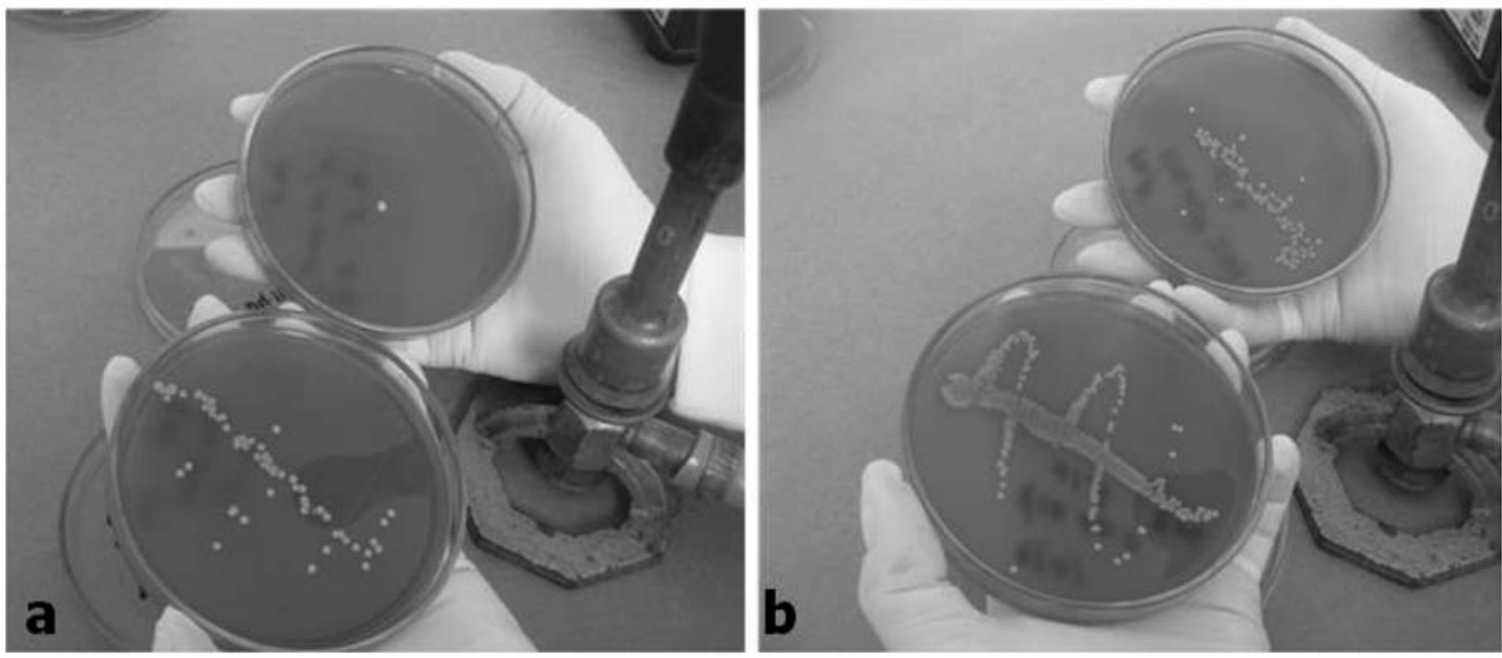

Figure 2. a) Comparison between a positive control group plate (left hand) and an equine platelet concentrate activated with calcium gluconate plate (right hand) at $8 \mathrm{~h}$; b) the same situation at $24 \mathrm{~h}$. It can be observed that the activated equine platelet concentrate produces a significant inhibition of bacterial growth in comparison with the positive control group.

a) Comparación entre una placa del grupo control positivo (mano izquierda) y una placa con concentrado de plaquetas de equino activado con gluconato de calcio (mano derecha) a las 8 h; b) La misma situación a las 24 h. Se observa que el concentrado de plaquetas de equino activado produce una inhibición significativa del crecimiento bacteriano en comparación con el grupo control positivo.

between $8 \mathrm{~h}$ and $12 \mathrm{~h}$ and $24 \mathrm{~h}$ and, between 12 and $24 \mathrm{~h}$. No differences were observed for bacterial growth in the PCG between $4 \mathrm{~h}$ and $8 \mathrm{~h}$ (figure $3 \mathrm{a}$ ).

The ePC group produced a sustained inhibition of the bacterial growth during first $12 \mathrm{~h}$, and then of the eighth hour showed an exponential growth until $24 \mathrm{~h}$; although this phenomenon was not as marked as the observed for the PCG. When each time point for the ePC group was compared, significant $(\mathrm{P}<0.01)$ differences were noticed between $1 \mathrm{~h}$, and $8 \mathrm{~h}, 12 \mathrm{~h}$ and $24 \mathrm{~h}$, between $4 \mathrm{~h}$ and, $8 \mathrm{~h}$, $12 \mathrm{~h}$ and, $24 \mathrm{~h}$, and among $12 \mathrm{~h}$ and $24 \mathrm{~h}$. No differences were noticed among $1 \mathrm{~h}$ and $4 \mathrm{~h}$ (figure $3 \mathrm{~b}$ ). The antibacterial effect observed during time for the ePC group was similar for the ePC/CG and PPP/CG groups (figure 3c-d).

The plasma group showed a sustained inhibition of the bacterial growth during first 8 hours and then presented an exponential bacterial growth very similar to the PCG, especially at $24 \mathrm{~h}$ (figure $3 \mathrm{e}$ ). The most important antibacterial effect of the plasma group was observed at $4 \mathrm{~h}$, when a complete inhibition of the bacterial growth was registered. In general, significant $(\mathrm{P}<0.01)$ differences for each time $(1,4,8,12$ and $24 \mathrm{~h})$ were observed in the plasma group. In addition, the time factor significantly influenced $(\mathrm{P}<0,01)$ the bacterial growth among all the 


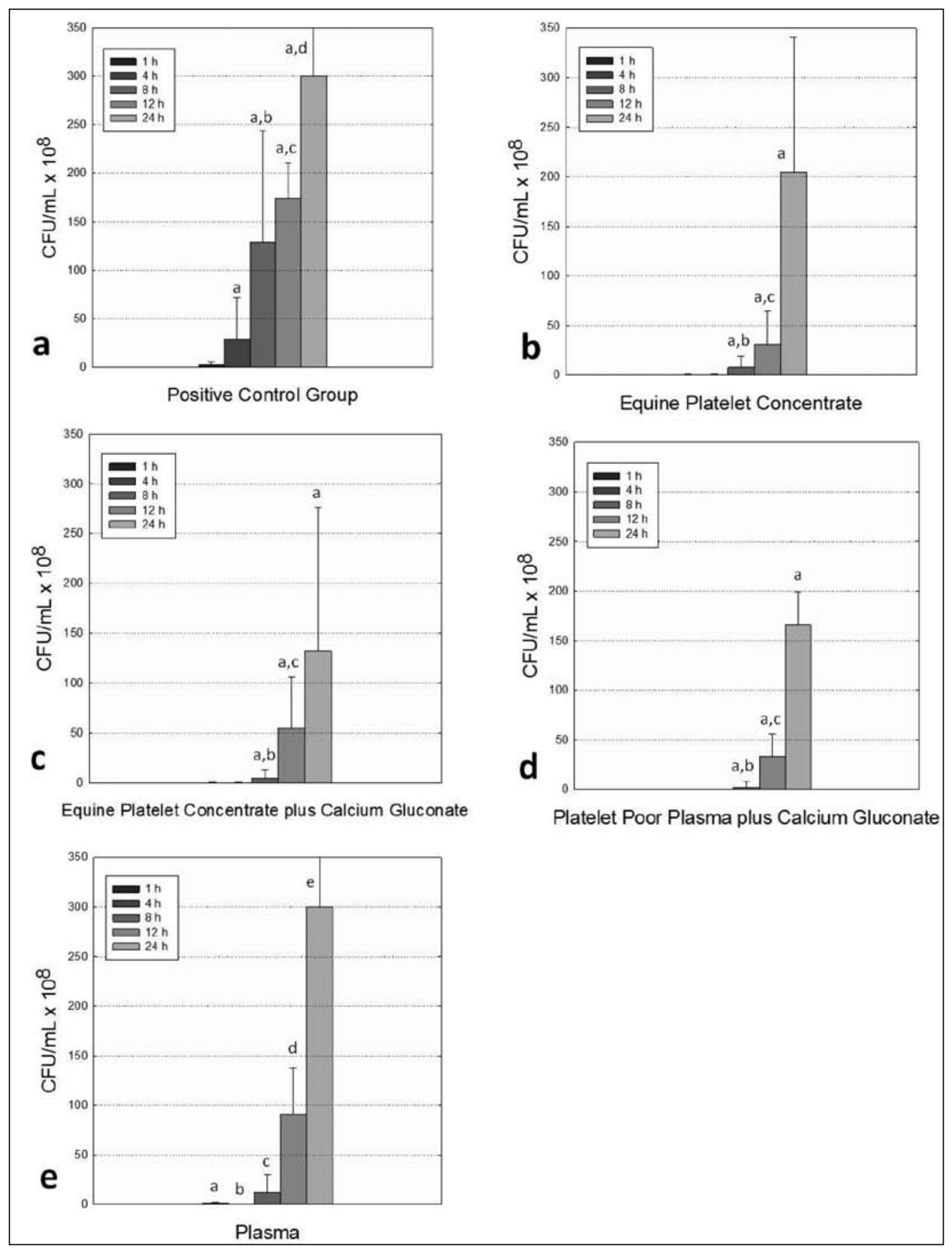

Figure 3. Plots data as $\mathrm{Y}$ values with interquartile ranges of the median values for $\mathrm{CFU} / \mathrm{mL} \times 10^{8}$ for each group during time. a) Positive control group: a Significantly different from $1 \mathrm{~h}$. b Significantly different from 12 and $24 \mathrm{~h}$. 'Significantly different from $12 \mathrm{~h}$. b) Equine platelet concentrate (ePC) group: a Significantly different from $1 \mathrm{~h}$ and $4 \mathrm{~h}$. ${ }^{\mathrm{b}}$ Significantly different from $12 \mathrm{~h}$ and $24 \mathrm{~h}$. ${ }^{\mathrm{c}}$ Significantly

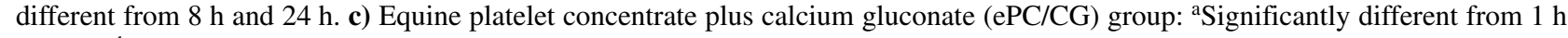
and $4 \mathrm{~h}$. ${ }^{\mathrm{b}}$ Significantly different from $12 \mathrm{~h}$ and $24 \mathrm{~h}$. ${ }^{\mathrm{c}}$ Significantly different from $8 \mathrm{~h}$ and $24 \mathrm{~h}$. d) Platelet poor plasma plus calcium gluconate (PPP/CG) group: a Significantly different from $1 \mathrm{~h}$ and $4 \mathrm{~h}$. ${ }^{\mathrm{b}}$ Significantly different from $12 \mathrm{~h}$ and $24 \mathrm{~h}$. 'Significantly different from $8 \mathrm{~h}$ and $24 \mathrm{~h}$. e) Plasma (P) group: ${ }^{\mathrm{a}-\mathrm{e}}$ Different letter represent significant differences for each time.

Gráficos de datos como valores de Y con rango intercuartílico y medianas de UFC/ml x $10^{8}$ para cada grupo en el tiempo. a) Grupo control positivo: aSignificativamente diferente de $1 \mathrm{~h}$. ${ }^{\mathrm{b}}$ Significativamente diferente de $12 \mathrm{y} 24 \mathrm{~h}$. ${ }^{\mathrm{c}}$ Significativamente diferente de $12 \mathrm{~h}$. b) Grupo concentrado de plaquetas equinas (ePC): a Significativamente diferente de $1 \mathrm{~h} \mathrm{y} 4 \mathrm{~h}$. ${ }^{\mathrm{b}}$ Significativamente diferente de $12 \mathrm{~h}$ y $24 \mathrm{~h}$. ${ }^{\mathrm{c}}$ Significativamente diferente de

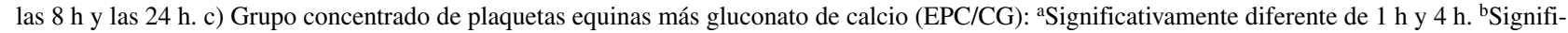
cativamente diferente de $12 \mathrm{~h} \mathrm{y} 24 \mathrm{~h}$. 'Significativamente diferente de las $8 \mathrm{~h}$ y las $24 \mathrm{~h}$. d) Grupo plasma pobre en plaquetas más gluconato de calcio (PPP/CG): 'a Significativamente diferente de $1 \mathrm{~h} \mathrm{y} 4 \mathrm{~h}$. ' ${ }^{\mathrm{b}}$ Significativamente diferente de $12 \mathrm{~h}$ y $24 \mathrm{~h}$. 'Significativamente diferente de las $8 \mathrm{~h}$ y las $24 \mathrm{~h}$. e) Grupo Plasma (P): ${ }^{a-e}$ Diferentes letras representan diferencias estadísticamente significativas para cada tiempo. 
evaluated groups (excepting the NCG), but this effect was more pronounced on P and PCG groups.

There were non-significant correlations between the concentrations of PLT or WBC of each group and the counts for $\mathrm{CFU} / \mathrm{mL}$.

\section{DISCUSSION}

The in vitro antibacterial effect of human PRP against MRSA has been previously reported (Bielecki et al 2007). However, this is the first study that describes the antibacterial effect of equine platelet concentrates (activated or not with CG) and activated PPP against MRSA. Our study corroborates a bacteriostatic effect for the equine plasma against Staphylococcus aureus (Bauer et al 2004). The antibacterial behaviour of the equine blood components evaluated in this study against MRSA should be evaluated taking into account at least 4 factors: 1) concentration of platelets, 2) plasma humoral proteins (Miajlovic et al 2007), 3) presence of platelet activating substance and, 4) time.

It is notable that activated PPP (PPP/CG) showed a similar antibacterial effect when compared to the ePCs evaluated during the experiment, especially when it is considered that this fraction contained significantly less PLT and WBC than ePC or ePC/CG. Activated PPP presented a better bactericidal action against MRSA in comparison with the plasma group during the 8,12 and $24 \mathrm{~h}$, suggesting that the antibacterial effect (against MRSA) of the equine blood components evaluated in this in vitro system may be related with complex cellular and molecular mechanisms that likely include the PLTs (and their degranulation microbicidal proteins) and the humoral components of the plasma (Bauer et al 2004, Moojen et al 2008).

In accordance to the observations from this study, Moojen et al (2008) found that the concentration of WBC did not present a correlation with the antibacterial effect of platelet gel or PRP against Staphylococcus aureus. We believe that the microbicidal proteins stored in platelets (Blair y Flaumenhaft 2009, Yeaman 2010) of the equine cellular blood components evaluated, are potentially the main mediators of antibacterial effects in this study. Possibly, the bactericidal mechanism of action for ePCs and PPP against MRSA could in part be related with a receptor saturable system of the bacterial cell wall (Trier et al 2008). This notion may explain how counts of PLTs as low as those observed in the equine PPP of this study were enough to induce bactericidal activity.

The ePCs (activated or not with CG) and activated PPP showed a sustained bactericidal effect during first $12 \mathrm{~h}$ and then presented a bacteriostatic action until 24 $\mathrm{h}$ in comparison with the plasma group, which showed a bacteriostatic behavior during first $8 \mathrm{~h}$ and gradually lost its effect after $12 \mathrm{~h}$ post-incubation. It is possible that in this in vitro system the equine cellular blood components required of humoral mechanisms (complement system (Miajlovic et al 2007) and $\mathrm{G}$ immunoglobulin activation) (Bauer et al 2004) and platelets (Moojen et al 2008) to exhibit a sustained antibacterial activity against MRSA. Possibly, the combination of these two immunologic mechanisms conferred to ePCs and PPP a synergistic bactericidal effect against MRSA and maybe, the absence of PLT in the plasma only produced a slight bacteriostatic effect to this substance. The results of this research demonstrated that the bactericidal or bacteriostatic effects of the evaluated equine blood components, could be associated with a gradual intake of humoral proteins followed by degradation of PLT or their derived microbicidal proteins. However, the bacteriostatic (or even bactericidal) contribution of the humoral termolabile mechanisms of the equine plasma via measurement of the complement activation pathways was no considered in this study.

During local or systemic disease the alpha-granule reaction release can be activated by interaction of platelet membrane glycoprotein Ib with Staphylococcus aureus (Shenkman et al 1999). This same situation was noticed in our in vitro study. However, although no differences were found, we observed a best tendency $(\mathrm{P}=0,1)$ of the antibacterial effect of the ePCs activated with CG followed by the activated PPP in comparison with the ePC alone. It is possible that calcium salts produced a better and more sustained release of platelet (microbicidal) proteins (Argüelles et al 2006) than the only stimuli with Staphylococcus aureus. However, the platelet concentration derived from microbicidal proteins was not measured in this study.

This research supplies basic information about the in vitro antibacterial behaviour of equine cellular blood components against MRSA. These results could have a potential clinical use, since these autologous substances could be used as prophylactic or therapeutic antibacterial biodrugs in several situations including soft tissue and orthopaedic equine surgery, or for the treatment of local infections (i.e.: septic arthritis or synovitis and abdominal or other incisional wounds) produced by MRSA (Anderson et al 2009). However, clinical and experimental studies should be performed to know the real therapeutic potential of these cellular blood products (ePC or PPP) in equine practice.

The analysis of the results of this study demonstrated that ePCs (activated or not with CG) and activated PPP provided a sustained in vitro antibacterial effect against MRSA in comparison with the plasma. It is possible that the equine plasma did not present an in vitro antibacterial action similar to the other equine cellular blood products, perhaps due the consumption or denaturation of humoral plasma components with effect against MRSA and the absence of platelets.

\section{SUMMARY}

\footnotetext{
The aims of the study were 1) to evaluate the antibacterial effect of equine platelet concentrates (ePCs) (either activated or not with calcium gluconate (CG)) against methicillin-resistant Staphylococcus aureus
} 
(MRSA), and 2) to compare their antibacterial effect with activated platelet poor plasma (PPP) and plasma $(\mathrm{P})$. Blood products were allotted in 4 groups $(\mathrm{ePC}, \mathrm{ePC} / \mathrm{CG}, \mathrm{PPP} / \mathrm{CG}$, and $\mathrm{P}$ ) plus a positive control group (PCG) and a negative control group, and mixed with MRSA and Mueller-Hinton broth. Samples were incubated during 1, 4, 8, 12, and $24 \mathrm{~h}$, and colony-forming units were counted. The bacterial growth was significantly $(\mathrm{P}=0.01)$ inhibited by the $\mathrm{ePC}, \mathrm{ePC} / \mathrm{CG}, \mathrm{PPP} / \mathrm{CG}$ and $\mathrm{P}$ in comparison with the PCG during the first $12 \mathrm{~h}$. At $24 \mathrm{~h}$ only a statistically significant $(\mathrm{P}=0.01)$ antibacterial effect was noticed for the ePC, ePC/ CG and PPP/CG in comparison with the PCG and P. Equine PCs and PPP provided the best in vitro antibacterial effect against MRSA.

\section{ACKNOWLEDGEMENTS}

The authors would like to thank Miguel Londoño, MVZ, Claudia M. Gutiérrez, BSc, Margarita Diaz and Jorge J. Gómez (r.i.p) for their technical assistance.

\section{REFERENCES}

Alvarez ME, CE Giraldo, JU Carmona. 2010. Bacterial contamination in platelet concentrates of horses. Arch Med Vet 42, 49-56.

Anderson MEC, SL Lefebvre, SC Rankin, H Aceto, PS Morley, JP Caron, RD Welsh, TC Holbrook, B Moore, DR Taylor, JS Weese. 2009. Retrospective multicentre study of methicillin-resistant Staphylococcus aureus infections in 115 horses. Equine Vet J 41, 401-405.

Argüelles D, JU Carmona, J Pastor, A Iborra, L Vinals, P Martinez, E Bach, M Prades. 2006. Evaluation of single and double centrifugation tube methods for concentrating equine platelets. Res Vet Sci 81, 237-245.

Bauer SM, EM Santschi, J Fialkowski, MK Clayton, RA Proctor. 2004. Quantification of Staphylococcus aureus adhesion to equine bone surfaces passivated with Plasmalyte (TM) and hyperimmune plasma. Vet Surg 33, 376-381.

Bielecki TM, TS Gazdzik, J Arendt, T Szczepanski, W Krol, T Wielkoszynski. 2007. Antibacterial effect of autologous platelet gel enriched with growth factors and other active substances-An in vitro study. J Bone Joint Surg Br 89B, 417-420.

Blair P, R Flaumenhaft. 2009. Platelet alpha-granules: Basic biology and clinical correlates. Blood Rev 23, 177-189.

Carmona JU, D Arguelles, M Prades. 2008. Transforming growth factor beta-3 and nitric oxide levels in four autologous platelet concentrates and plasma derived from equine blood. Arch Med Vet 40, 155-160.

Carmona JU, C Lopez, M Prades. 2009' . Use of autologous platelet concentrates obtained by the tube method as a treatment for arthropathies in horses. Arch Med Vet 41, 175-179.

Carmona JU, M Prades, D Arguelles. 2009 ${ }^{\mathrm{b}}$. Autologous platelet concentrates as a treatment for soft tissue musculoskeletal lesions in horses. Arch Med Vet 41, 77-82.

Ingle-Fehr JE, GM Baxter, RD Howard, GW Trotter, TS Stashak. 1997. Bacterial culturing of ventral median celiotomies for prediction of postoperative incisional complications in horses. Vet Surg 26, 7-13.

Karska-Wysocki B, M Bazo, W Smoragiewicz. 2010. Antibacterial activity of Lactobacillus acidophilus and Lactobacillus casei against methicillin-resistant Staphylococcus aureus (MRSA). Microbiol Res 165, 674-686.

Macdonald DG, PS Morley, JV Bailey, SM Barber, PB Fretz. 1994. An examination of the occurrence of surgical-wound infection following equine orthopedic-surgery (1981-1990). Equine Vet $J$ $26,323-326$.
Miajlovic H, A Loughman, M Brennan, D Cox, TJ Foster. 2007. Both complement- and fibrinogen-dependent mechanisms contribute to platelet aggregation mediated by Staphylococcus aureus clumping factor B. Infect Immun 75, 3335-3343.

Monteiro SO, OM Lepage, CL Theoret. 2009. Effects of platelet-rich plasma on the repair of wounds on the distal aspect of the forelimb in horses. Am J Vet Res 70, 277-282.

Moojen DJF, PAM Everts, RM Schure, EP Overdevest, A van Zundert, JTA Knape, RM Castelein, LB Creemers, WJA Dhert. 2008. Antimicrobial activity of platelet-leukocyte gel against Staphylococcus aureus. J Orthop Res 26, 404-410.

Mukhopadhyay K, W Whitmire, YQ Xiong, J Molden, T Jones, A Peschel, P Staubitz, J Adler-Moore, PJ McNamara, RA Proctor, MR Yeaman, AS Bayer. 2007. In vitro susceptibility of Staphylococcus aureus to thrombin-induced platelet microbicidal protein-1 (tPMP1 ) is influenced by cell membrane phospholipid composition and asymmetry. Microbiology 153, 1187-1197.

Pille F, A Martens, M Oosterlinck, M Dumoulin, J Dewulf, F Gasthuys. 2009. A retrospective study on 195 horses with contaminated and infected synovial cavities. Vlaams Diergeneeskund Tijds 78, 97-104.

Shenkman B, E Rubinstein, R Dardik, I Tamarin, N Savion, D Varon. 1999. Activated platelets mediate Staphylococcus aureus deposition on subendothelial extracellular matrix: the role of glycoprotein Ib. Platelets 10, 36-44.

Strukova EN, MV Smirnova, SN Vostrov, IY Lubenko, AA Firsov, SH Zinner, YA Portnoy. 2009. Linezolid pharmacodynamics with Staphylococcus aureus in an in vitro dynamic model. Int J Antimicrob Agents 33, 251-254.

Sutter WW, AJ Kaneps, AL Bertone. 2004. Comparison of hematologic values and transforming growth factor-beta and insulin-like growth factor concentrations in platelet concentrates obtained by use of buffy coat and apheresis methods from equine blood. Am J Vet Res $65,924-930$

Taylor AH, TS Mair, LJ Smith, JD Perkins. 2010. Bacterial culture of septic synovial structures of horses: Does a positive bacterial culture influence prognosis? Equine Vet J 42, 213-218.

Trier DA, KD Gank, D Kupferwasser, NY Yount, WJ French, AD Michelson, LI Kupferwasser, YQ Xiong, AS Bayer, MR Yeaman. 2008. Platelet antistaphylococcal responses occur through P2X(1) and $\mathrm{P} 2 \mathrm{Y}(12)$ receptor-induced activation and kinocidin release. Infect Immun 76, 5706-5713.

Waselau M, WW Sutter, RL Genovese, AL Bertone. 2008. Intralesional injection of platelet-rich plasma followed by controlled exercise for treatment of midbody suspensory ligament desmitis in Standardbred racehorses. J Am Vet Med Assoc 232, 1515-1520.

Weese JS. 2004. Methicillin-resistant Staphylococcus aureus in horses and horse personnel. Vet Clin N Am Equ Pract 20, 601-613.

Weese JS, SL Lefebvre. 2007. Risk factors for methicillin-resistant Staphylococcus aureus colonization in horses admitted to a veterinary teaching hospital. Can Vet J 48, 921-926.

Weese JS, J Rousseau. 2005. Attempted eradication of methicillin-resistant Staphylococcus aureus colonisation in horses on two farms. Equine Vet J 37, 510-514.

Yeaman MR. 2010. Platelets in defense against bacterial pathogens. Cell Mol Life Sci 67, 525-544.

Yount NY, KD Gank, YQ Xiong, AS Bayer, T Pender, WH Welch, PMR Yeaman. 2004. Platelet microbicidal protein 1: Structural themes of a multifunctional antimicrobial peptide. Antimicrob Agents Chemother 48, 4395-4404.

Yuan T, CQ Zhang, BF Zeng. 2008. Treatment of chronic femoral osteomyelitis with platelet-rich plasma (PRP): A case report. Transfus Apher Sci 38, 167-173. 